\title{
Evidence for a Waalian thermomer pollen record from the research borehole Heidelberg UniNord, Upper Rhine Graben, Baden-Württemberg
}

\author{
Jürgen Hahne, Dietrich Ellwanger \& RÜdiger Stritzke*)
}

\begin{abstract}
A pollen record from the borehole Heidelberg UniNord, in the northern Upper Rhine Graben shows evidence for one of the rare Waalian thermomers. The record may not comprise the complete thermomer it certainly reflects a sort of succession, initiated by sequences with high values of pine and spruce, followed by a dominance of pine, hemlock-spruce and spruce and finished by a dominance of hemlockspruce, oak and hornbeam becomes visible. Pollen percentage values for Tsuga reach $20 \%$ indicating that this taxon is an important forest element. There is a continuous presence of Carya, Pterocarya, Eucommia, Celtis and Ostrya-type. Neighbouring pollen records reveal similar patterns. The pollen diagram is closely related with the Waalian profiles Leerdam and Eindhoven from the Netherlands.
\end{abstract}

[Nachweis der Waal-Warmzeit anhand pollenanalytischer Untersuchungen an der Forschungsbohrung Heidelberg UniNord, Oberrheingraben, Baden-Württemberg]

Kurzfassung: Eine Pollensukzession aus der Bohrung Heidelberg UniNord im Oberrheingraben kann mit der bisher selten nachgewiesenen Waal-Warmzeit verknüpft werden. Das wohl nicht vollständig erfasste Thermomer reflektiert eine angedeutete Sukzession, die von einer basalen Fichten-Kiefernzeit über einen Abschnitt mit Kiefer, Hemlocktanne und Fichte, hin zu einer abschließenden Waldzeit verläuft, in der Hemlocktanne (Tsuga), Eiche und Hainbuche dominieren. Tsuga erreicht im Gesamtdiagramm Werte bis zu $20 \%$ und repräsentiert ein wichtiges Waldelement. Ständig vorhanden sind in geringen Anteilen ferner Carya, Pterocarya, Celtis, Eucommia und Ostrya-Typ. In Nachbarbohrungen deutet sich dasselbe Muster an. Das Pollendiagramm wird korreliert mit den Waal-Profilen aus Leerdam und Eindhoven (Niederlande).

Keywords: Upper Rhine Graben, pollen analysis, Waalian thermomer, biostratigraphy

* Adresses of authors: J. Hahne, Tiefenthal 3, 37586 Dassel; Germany. E-Mail: juergenhahne@gmx.de; D. Ellwanger, Regierungspräsidium Freiburg, Landesamt für Geologie, Rohstoffe und Bergbau, Albertstr.5, D79104 Freiburg/i.Br., Germany. E-Mail: dietrich.ellwanger@rpf.bwl.de; R. Stritzke, Geologischer Dienst NRW, De Greiff Str. 195, D-47707 Krefeld, Germany. E-Mail: ruediger.stritzke@gd.nrw.de 


\section{Introduction}

In order to develop a better understanding of the Pleistocene geological processes associated with the evolution of the Upper Rhine Graben (URG), a scientific core drilling has been brought down at the campus of Heidelberg University. In this location, one of the thickest successions of continental Quaternary deposits has been expected according to various pre-site surveys (Buness, Gabriel \& Ellwanger 2008). For technical reasons, a first borehole (Heidelberg UniNord1) has been cored down to $190 \mathrm{~m}$ in 2006, followed by a second borehole (UniNord2) down to $500 \mathrm{~m}$ in 2008. For a first summary of geological results, cf. ELLWANGER et al. (2008); for an outline of the Heidelberg project cf. GABriEL et al. (2008).

In this paper, only results from the first borehole $(0-190 \mathrm{~m}$; UniNord1) have been evaluated. According to Ellwanger et al. (2008), only about one third of the succession consists of fine-grained i.e. silt-dominated deposits. Out of these, only three intervals, altogether amounting to less than five meters of sediment core, turned out to be suitable for a detailed pollen analysis $(57-58 \mathrm{~m} ; 81-87 \mathrm{~m}$ and 180 $-181.70 \mathrm{~m}$ ). The remaining $65 \mathrm{~m}$ of silt-dominated sediments were poor in pollen-content. This may be due to oxidation and differential preservation of the pollen, e.g. concentration of thick-walled grains such as conifers and Tilia, but also of poor core quality.

The biostratigraphic review maybe summarized as follows:

(1) At $57-58 \mathrm{~m}$ and $82-85 \mathrm{~m}$ depth a pinespruce forest indicating cool climate;

(2) At $81-82 \mathrm{~m}$ and at $87 \mathrm{~m}$ depth a middle Pleistocene pollen spectrum without Fagus indicates an interglacial environment is indicated;

(3) At $180-181.70 \mathrm{~m}$ depth some very pollen rich samples were found in peaty sediments with more or less silt. The higher pollen percentage values of the genus Tsuga (Hemlock spruce) indicates a temperate "interglacial" resembling an early Pleistocene age.

This study is focused on the interval (3).

\section{Methods}

Peaty samples were taken at $10 \mathrm{~cm}$ intervals. In total, 17 pollen samples were analysed. Samples were subjected to HF $(70 \%)$ treatment followed by ultrasonic sieving (mesh size $6 \times 8 \mu \mathrm{m}$ ) then acetolysis. With the exception of the two oldest samples, arboreal pollen counts of at least 500 were attained. The basis for representation on the pollen diagram was the total pollen sum (all pollen types excluding aquatics and ferns). The pollen diagram (Fig. 2) was prepared using the plotting program Tilia (GRIMm 1991). Non-arboreal taxa that were only encountered in few samples and in low numbers are not shown on the diagram. Values below $1 \%$ are also represented (symbol "॰”).

\section{Results}

The pollen diagram (Fig. 1) is divided into three local pollen zones (A, B and C):

- A: $181.70-181.15$ m: Pinus - Picea zone (with ferns)

- B: $181.15-180.55 \mathrm{~m}:$ Pinus - Tsuga $-P i-$ cea zone

- C: 180.55 - 180.00 m: Tsuga-Quercus - Carpinus zone (with Alnus and Betula)

The local pollen assemblage zone A is characterized by a dominance of Pinus and Picea, ferns are of great importance. The arboreal taxa such as Tsuga, Ulmus, Corylus, Carpinus and Eucommia are present with rates up to $2 \%$, Quercus ranges between 2-5\%.

In zone B Tsuga (and Alnus) is increasing and represents an important forest element.

Zone C reflects a dominance of Tsuga (10$15 \%$ ), Quercus (10-15\%) and Carpinus (10$25 \%$ ) (together with Alnus and Betula). Pinus and Picea are of less importance. Typical elements of Older- and Middle Pleistocene such as Pterocarya, Eucommia, Carya, Celtis and Ostrya-type are continuously present in low rates. Fagus is limited to sample $180,10 \mathrm{~m}$ where two pollen grains are recorded.

Altogether, the succession is clearly dominated by arboreal taxa representing a thermomer stage i.e. warm climate. Non arboreal pollen 

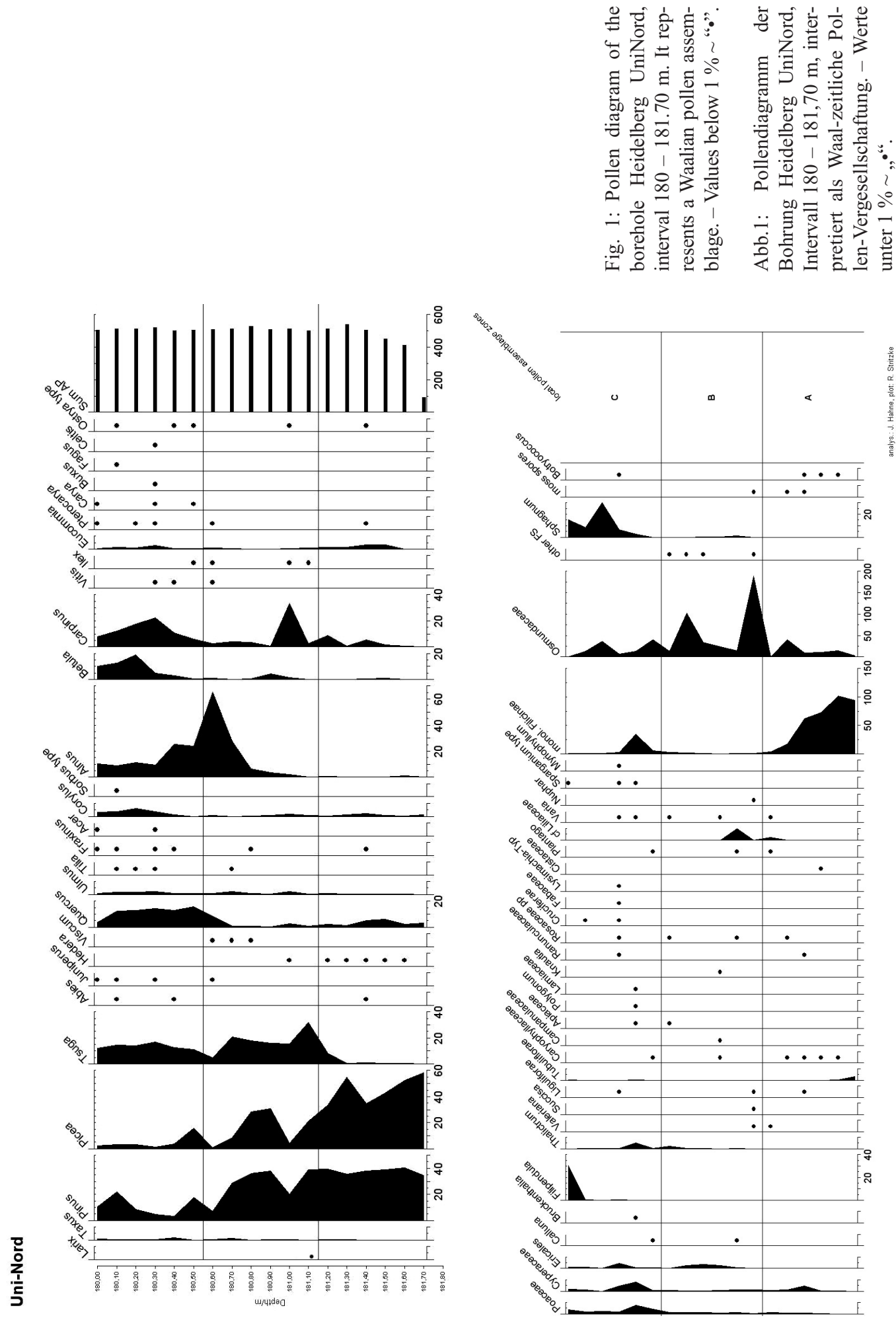


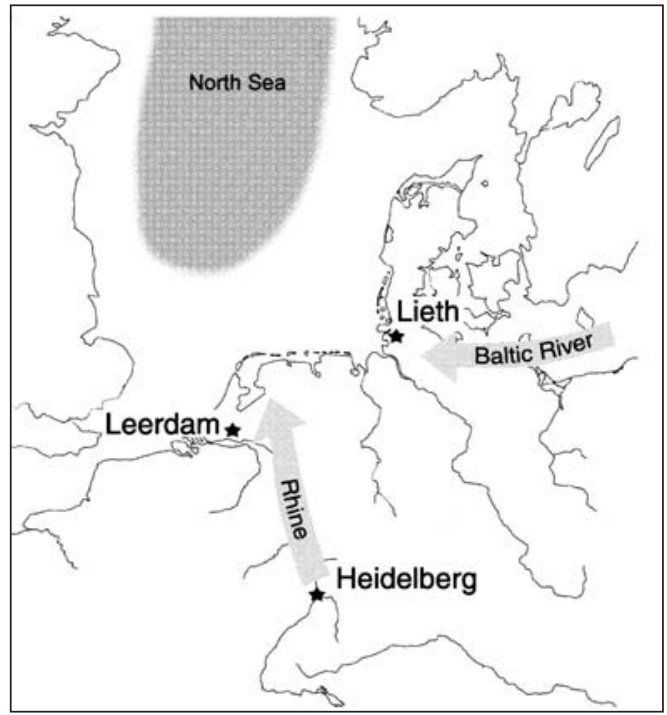

Fig. 2: Geographic position of Waalian sequences in middle Europe, Leerdam, Lieth, and Heidelberg. Present topography and palaeogeographical setting (GIBBARD 1988). Palaeo-shoreline uncertain, varying according to high and low sea level.

Abb. 2: Geographische Lage der Waal-Vorkommen in Mitteleuropa, Leerdam, Lieth und Heidelberg. Heutige Geographie und Waal-zeitliche Paläogeographie (GIBBARD 1988). Die Paläo-Küstenlinie ist unsicher, sie schwankt je nach Höhe des Meeresspiegels.

types are of less importance and mostly below $10 \%$, with the exception of two samples with Filipendula (up to $30 \%$ !) and an unknown, very small Liliaceae-type. Both elements represent the influence of local swampy vegetation.

\section{Discussion}

According to the implied succession of the significant arboreal taxa, the pollen diagram (Fig. 1) has been divided in three pollen assemblage zones. There are, however, no taxa, which are immigrating in the course of the sequence. All are present right from the beginning.

Complete sequences of the immigration of tree species during an interglacial cycle (e.g. shrubs - birch - pine - broad leaf trees - climax zone - conifers) is well known from the Holocene, from the Eemian, and from middle Pleistocene thermomers (Holsteinian, Cromerian). These characteristics are also reported from Bavelian sequences (ZAGwiJn \& De Jong 1984). However, as indicated above, this type of succession is not recorded in the Waalian thermomer, the older Pleistocene (Tiglian thermomers) and the Reuverian.

The decrease of arboreal taxa during the Pleistocene is known from various studies. Pterocarya is ultimately recorded at the end of the Holsteinian (e.g. Beaulieu \& Monjuvent 1985).

Eucommia and Celtis barely occupy interglacial I and II of the Cromerian-Complex, e.g. Homann \& Lepper (1994), Hahne (1996a,b). Van Der Hammen et al. (1971) record Carya and Ostrya-type restricted to the Older Pleistocene thermomers Waalian and Tiglian. ZAGWIJN \& DE JoNG (1984) report from the cores from Bavel, Netherlands, i.e. the type region of the Bavelian stage, also Carya, Ostrya-type and Tsuga.

Tsuga was the first taxon recognised as an element of the Older Pleistocene (e.g. by VAN DER Hammen et al., 1971). According to ZaGwiJn (1957, 1960) and HAHNE (1996a,b), this taxon is present in low levels in the Reuverian and in the Pretiglian as well as in the Tiglian A, B and C. KNIPPING (2004) recorded single pollen grains in sediments of Bavelian age, whereas ZAGWIJN \& De Jong (1984) report values up to $30 \%$ in a profile in Bavel revealing also a distinct succession of the tree species. Quite recently, KNIPPING (2008) even stated a single pollen grain of Tsuga in a thermomer, which she assumed to belong to the Cromerian Complex.

On the other hand, Pliocene elements such as Liquidamdar, Nyssa, Sciadopitys, Taxodiumand Sequoia-habitus are not present in the pollen diagram (Fig. 1). All those are frequent in the Reuverian and, with the exception of Sciadopitys, very sparsely during Tiglian (ZAGWIJN 1960, 1963, 1989). Some very first results of the lower parts of the Heidelberg UniNord borehole confirm this trend (ELLwANGER et al. 2008, Fig. 3). 


\section{Conclusions}

The pollen diagram (Fig. 1) reflects a thermomer revealing a closed forest vegetation in which pine, spruce, Hemlock-spruce, oak, hornbeam and elder were dominant. Records of Older Pleistocene elements (Pterocarya, Eucommia, Celtis, Carya, and Ostrya-type) are continuously present but only in low numbers. A successive immigration is not visible.

All these characteristics exclude an assignment of this thermomer to young or middle Pleistocene stages. A correlation with the Reuverian is also not possible due to the missing of Pliocene elements. For the Tiglian the presence of Sciadopitys, Nyssa, Liquidambar, and Pinus haploxylon-Habitus is compulsive. Therefore, only the Waalian and the Bavelian stages are to be taken on closer consideration.
After Zagwijn \& De Jong (1984), the Bavelian fills an intermediate position between Older- and Middle Pleistocene. With respect to partly high values of Tsuga, the presence of Ostrya-type, Celtis and Eucommia an Older Pleistocene character is evident whereas a succession of the expansion of various trees due to differences in re-immigration emphasizes a strong resemblance with thermomers younger than Tiglian and Waalian.

The pollen diagram (Fig. 1) shows significant similarities with the Leerdam-Profile (Fig. 2) which is the type locality for Waalian (ZAGwiJn \& De Jong 1984). The similarity is not restricted only to the spectra of the arboreal pollen types, but also in their values (with the exception of Picea, which in Leerdam has a smaller representation). Different with Leerdam is also the missing of indications of systematic suc-

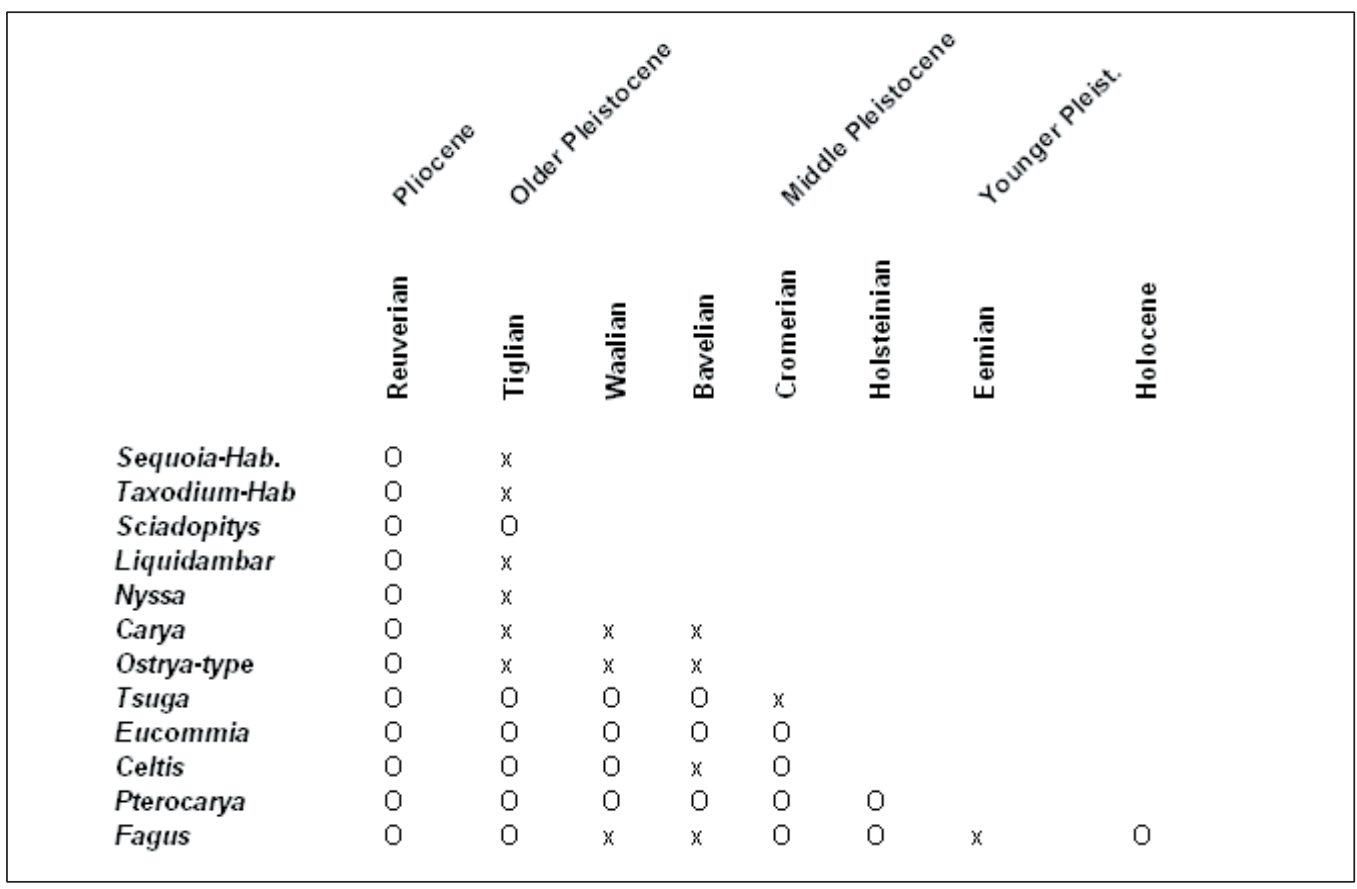

Fig. 3: Presence of important arboreal taxa in Middle European pollen sequences from the Reuverian (Pliocene) to the Holocene. Adapted from Lang (1994), updated according to actual investigations and with regard to new results from the Heidelberg research boreholes. - Symbols: $\mathrm{O}=$ frequent, $\mathrm{x}=$ rare.

Abb. 3: Vorkommen wichtiger Baumpollen in mitteleuropäischen Pollensequenzen vom Reuver (Pliozän) bis ins Holozän. Nach LANG (1994), fortgeschrieben aufgrund neuer Untersuchungen, insbesondere neuen Ergebnissen aus den Forschungsbohrungen Heidelberg. - Symbole: $\mathrm{O}=$ häufig, $\mathrm{x}=$ selten. 
cession in immigration and culmination of the individual trees.

In Kronau, about $20 \mathrm{~km}$ south of Heidelberg, another borehole revealed cores of peaty sediments at depths around $85 \mathrm{~m}$. Here several pollen samples reveal nearly identical Waalian pollen assemblages as in Heidelberg.

ZAGWIJN (1989) noted that the Waalian generally has the character of an interglacial complex consisting of an interstadial situated between two thermomers. A similar sequence is recorded by Menke (1976) for the "Tornesch thermomer" (Lieth series) situated in Schleswig-Holstein which is also assigned to the Waalian. Although it reveals a domination of Ericales (pointing toward Atlantic heaths) apart from Tsuga all Older Pleistocene elements are present. Running analysis on the cores of the UniNord2 borehole at Heidelberg reveal $26 \mathrm{~m}$ underneath the peaty Waalian sediments again typical Waalian pollen sequences which possibly could assigned to the older Waalian thermomer. The intermediate sediments are fluvial gravels, which, unfortunately, are poor of pollen so that their climatic character is still uncertain. Even a separation within either the upper or the lower thermomer by fluvial gravels, without any difference in climate, may be considered.

The question remains why there are such great similarities in the forest vegetation between the Upper Rhine Graben and the Netherlands, whereas from Lieth (Schleswig-Holstein, Fig. 2) a quite different forest vegetation and maritim influenced different climatic conditions has been reported by Menke $(1969,1976)$. In our view, this indicates uniform climate conditions along the Rhine, and different conditions further east. Today the Rhenish Schist highlands act as a barrier between the Netherlands and the Upper Rhine Graben. In the Waalian stage, prior to their major uplift, the Rhenish Schist was an area of some low hills. In this scenario, there was an almost flat landscape from Heidelberg to the Netherlands, with uniform forest vegetation and climate conditions (Fig. 2).

However, K.-E BeHRE (Wilhelmshaven) has expressed another view (pers. comm.). The Neth- erlands situated in the lower Rhine area, were an excellent sediment and pollen catching area, including reworked pollen from further south. Their pollen records reflect the complete upper Rhine vegetation combined with the regional elements. On the other hand, the Lieth series (MENKE 1976) reflects the regional vegetation of Holstein, maybe including input from the Baltic river system (Fig. 2).

The chronostratigraphic age of the Waalian amounts to 1.1 -1.3 Ma (ZAGWIJN 1989) or to 1.4 - 1.6 Ma (OGG, OGG \& Gradstein 2008), both with duration of approximately $200 \mathrm{ka}$. Thus, the peaty sequence from Heidelberg (Fig. 1) with a length of $1.7 \mathrm{~m}$ does certainly not reflect one of the two thermomers as a whole, but only a shorter period belonging to either of them.

Considering the arboreal pollen types, the climate of the recorded sequence was probably not warmer than today. The present day distribution of the most important Tsuga species (T.canadensis and T. diversifolia) in NorthEast America and East Asia reflect mountainous climates and moist habitats.

According to DE Jong (1988), many of the socalled Pliocene trees that are today restricted to North America or East Asia, actually do very well in European parks or as forest elements. Thus, the interglacial climates of the Early Pleistocene might not have been more favourable than in the middle or young Pleistocene, but the intermediate stadials were not as extreme as the glacial stages of that period.

Thus, for the identification of a Waalian thermomer in Middle Europe three conditions must be fulfilled:

1. no complete succession of the arboreal genera,

2. Tsuga must be an important member of the forest vegetation, and

3. there must be at least single records of so called Older Pleistocene elements such as Eucommia and Pterocarya and in very low rates also Carya, Celtis and Ostrya-type and possibly even Fagus.

Final remark: In summer 2008, a second drilling in Heidelberg (“UniNord2") finally reached 
its planned depth of $500 \mathrm{~m}$. First scans of pollen content down to $499.94 \mathrm{~m}$ include continuous findings of Fagus and Carya as well as such of Sciadopitys, Nyssa, Pinus haploxylon, Cupressaceae, Sequoia- and Taxodium-habitus. The spectra are clearly different from the Waalian and represent most likely the Tiglian interval. By now, we also know that the thickness of the Quaternary at the UniNord location will amount to more than $500 \mathrm{~m}$ (well exceeding the originally assumed thickness of $\sim 400 \mathrm{~m}$ ). The Reuverian is expected well below $500 \mathrm{~m}$.

\section{Acknowledgements}

The pollen samples were prepared at the HF-laboratory of Prof. Dr. H. Behling, Göttingen. We are thankful to Prof. Dr. K.-E. Behre, Wilhelmshaven, who commented on the pollen diagram and gave us useful advice. Dr. Ulrike WielandtSchuster, Freiburg, helped with fruitful remarks and design of figures. Dr. Ellyn Cook, Göttingen, reviewed the text as a native speaker.

\section{References}

Beaulieu, J.-L. De \& Montuuvent, G. (1985): Données actuelles sur la formation Interglaciaire de Pompillon (Pleistocène moyen), Val de Lans et Vercors (Isère, France). - Bull. A.F.E.Q., 2/3: 75-83.

Buness, H., Gabriel, G. \& Ellwanger, D. (2008): The Heidelberg Basin drilling project: Geophysical pre-site surveys. - Quaternary Science Journal (Eiszeitalter und Gegenwart), 57/3-4: 338-366.

DE Jong, J. 1988: Climatic variability during the past three million years, as indicated by vegetational evolution in northwest Europe and with emphasis on data from the Netherlands. - Philosophical Transactions of the Royal Society of London, B318: 603-617.

Ellwanger, D., Gabriel, G., Simon, T., WielandtSchuster, U., Greiling, R.O., Hagedorn, E.-M., Hahne, J. \& Heinz, J. (2008): Long sequence of Quaternary Rocks in the Heidelberg Basin Depocentre. - Quaternary Science Journal (Eiszeitalter und Gegenwart), 57/3-4: 316-337.

Gabriel, G., Ellwanger, D., Hoselmann, C. \& WeiDENFEller, M. (2008): Preface: The Heidelberg
Drilling Project - Quaternary Science Journal (Eiszeitalter und Gegenwart), 57/3-3: 253-269.

GibBard, P.L. (1988): The History of the Great Northwest European Rivers during the Past Three Million Years. - Philosophical Transactions of the Royal Society of London, B318: 559-600.

GrImM, E.C. (1991): Tilia version 2.0.B.4, Tiliagraph verdion 2.0 and Tiliagraph View Version 1.0.5.2, Research and Collection Section, Illinois State Museum, Illinois

Hahne, J. (1996a): Pollenanalytische Untersuchungen an den Bohrkernen 89/4 und 89/9, südliche Nordsee. - Geologisches Jahrbuch, A 146: 163-175.

HAHNe, J. (1996b): The Interglacial site of Hunteburg, near Quakenbrück (NW Germany). - In: Turner, C. (ed.): The early Middle Pleistocene in Europe: 181-186; Rotterdam (Balkema).

Homann, M. \& Lepper, J. (1994): Das Cromer-Profil von Solingen (Süd-Niedersachsen) - Geologisches Jahrbuch, A134: 211-228.

KnIPPING, M. (2004): Pollenanalytische Untersuchungen an einem mittelpleistozänen Interglazial bei Mannheim. - Tübinger Geowissenschaftliche Arbeiten, 10: 199-217.

KnIPPING, M. (2008): Early and Middle Pleistocene pollen assemblages of deep core drillings in the northern Upper Rhine Graben, Germany. - Netherlands Journal of Geosciences - Geologie en Mijnbouw, 87/1: 51-65.

LANG, G. (1994): Quartäre Vegetationsgeschichte Europas. Methoden und Ergebnisse. - 462p. Jena (Gustav Fischer Verlag).

Menke, B. 1969: Vegetationsgeschichtliche Untersuchungen an altpleistozänen Ablagerungen aus Lieth bei Elmshorn. - Eiszeitalter und Gegenwart, 20: 76-83.

Menke, B. (1976): Vegetationsgeschichte und Florenstratigraphie Nordwestdeutschlands im Pliozän und Frühquartär. Mit einem Beitrag zur Biostratigraphie des Weichsel-Frühglazials. - Geologisches Jahrbuch, A26: 3-151.

OgG, J., OGG, G. \& Gradstein, F. (2008): The Concise Geologic Time Scale. - 184p.; Cambridge (Cambridge University Press).

Van Der Hammen, T., Wijmstra, T.A. \& Zagwijn, H.W. (1971): The Floral Record of the Late Cenozoic of Europe. - In: TureKian, K.K.(ed.): The Late Cenozoic Glacial Ages: 391-424; New Haven, London (Yale University Press).

ZAGWIJN, H.W. (1957): Vegetation, climate and time correlation in the Early Pleistocene of Europe. - Geologie en Mijnbouw,N.S.19: 233-244. 
ZaGwisn, H.W. (1960): Aspects of the Pliocene and early Pleistocene vegetation in the Netherlands. - Mededelingen Geologische Stichting, Serie C-III, 5: 5-78.

ZAGWIJN, H.W. (1963): Pollen-analytic investigations in the Tiglian of the Netherlands. - Mededelingen Geologische Stichting, N.S., 16: 49-72.

ZAGWIJN, H.W. (1985): An outline of the Quaternary stratigraphy of the Netherlands. - Geologie en Mijnbouw, 64: 17-24.
Zagwisn, H.W. (1989): The Netherlands during the Tertiary and the Quaternary: A case history of Coastal Lowland evolution. - Geologie en Mijnbouw, 68: 107-120.

ZagwiJn, H.W. \& De Jong, J. (1984): Die Interglaziale von Bavel und Leerdam und ihre stratigraphische Stellung im niederländischen FrühPleistozän. - Mededelingen Rijks geologische Dienst, 37/3: 155-169. 